developments in biology and medicine". Although it has been written from an American point of view, it is relevant for all those who have to deal with bioethical dilemmas on the level of society.

The author explores the various responses of American law (ie common law, legislation, administrative law-making and constitutional adjudication) to today's major moral dilemmas related to medicine. After an introduction to the (at least for non-anglo-saxons) complicated American legal system, he discusses the following issues: abortion, (compulsory) sterilization, alternative reproductive techniques, genetics, death and dying, and experimentation with human beings.

Dworkin's starting-point is that "morally questionable law, (ie law on issues that are per se morally debatable HMD) should be reserved for areas in which moral consensus exists in the society" (page 20); if there is no consensus, it is better to have no law at all. But laws exist; in most countries, including the USA, abortion - for instance - was criminalized. Thus "the most important reform would simply be to repeal the criminal prohibitions" (page 20). By 1973 fourteen states in the USA had indeed revised their criminal anti-abortion statutes. But the reformers wanted more, they wanted a "right" to abortion, which resulted in the end in the Supreme Court's famous "Roe $v$ Wade" decision, which favoured the pro-choice position. Dworkin demonstrates that the drive to pursue legal actions up to the Supreme Court, led in fact to a very unattractive "Pyrrhic victory". At first sight the right to abortion seemed to be gained for everyone in the US, but "Roe $v$ Wade" was a disaster for people who care about law". The shortcomings of its argumentation led to a number of unclear decisions by other courts. "Thinking big ultimately led to the downfall of the apparently victorious reformers and did other harm as well" (page 53). This conclusion may be right, but the author does not mention the fact that till 1973 only a minority of US states had reformed their law. One wonders which other option was available for the reformers, and whether the US law system as such was the cause of all problems. Other countries did indeed decriminalize abortion by legislative reform without the problems Dworkin came across in the US legal development. In the meantime Dworkin's analysis of the arguments used in the legal battles are interesting, from an ethical, as well as a legal, point of view. His analysis, for instance of the hazards of a "rights language", of the significance of privacy, and of the "viability of the fetus" criterion, are precise and valuable.

End-of-life decisions also cause harsh legal and moral dilemmas. Here Dworkin notes an "enormous gap" between a "highly restrictive law" and "highly permissive practice" (again in the USA), at least till 1976 (the year of the Quinlan case). Although, as Dworkin writes, from a certain point of view one could regard the pre-1976 period as being "as close to ideal as a system designed and run by mortals can be" (page 113), a movement started to change the law. The following judicial fights and legal reforms demonstrate again the limited possibilities of the law to cope with these moral problems. The issue of facilitating death is very complicated (page 109f). Decriminalizing such decisions, as Dworkin advocated in relation to abortion, is apparently no option in this case. One may wonder why. It may be understandable and defendable in relation to active euthanasia, (because of its association with "murder"), but foregoing or refusing medical treatment is obviously something very different from murder. What would be easier than to declare the criminal prohibition of murder not applicable to refusals of medical treatment? It is exactly the analogy between "non treatment decisions" and "murder" that enforces the supremacy of tubes and pills over people. And although Dworkin observes with regret that the judicial and legislative approaches "have not solved the problems and have not created a situation in which patients can feel secure that their wishes will be followed", he does not advocate a decriminalizing of "end of life" decisions. This is hardly consistent with one of the conclusions of the book that "the law fails most miserably when it tries to regulate most fully or to take principled positions. It comes closest to succeeding when it hardly regulates at all" (page 164). As a consequence of this conclusion one would expect a plea for less law concerning facilitating death.

This interesting book leaves the reader with the conviction that most moral dilemmas should be solved at an individual level without interference from the law: this is actually Dworkin's starting-point. And, in the opinion of this reviewer, it is becoming clear also, that the discipline of ethics is much better at dealing with modern medicine, than the law ever could be.

HELEEN M DUPUIS

Professor of Medical Ethics, Leiden University the Netherlands

\section{Helping and Healing: Religious Commitment in Health Care}

E D Pellegrino and D C Thomasma, Washington, DC, Georgetown University Press, 1997, 167 pages, $£ 12.50, \$ 15.95$.

The stated aim of this book is "to develop a more complete account of a moral philosophy for medicine", recognising the place of human reason within faith, but "illumined by the authoritative word of Scripture and tradition" (page 1).

The authors' goal is to demonstrate the possibilities of enriching and broadening the ethical enterprise, through the use of a religious perspective, by concentrating on the ways in which a religious perspective shapes the healing relationship and the ethics of that relationship.

Noting the "dilemma for our times" as being the clash between the values of technology and the values of medicine, the authors believe the use of advances must be governed by human and moral ends.

The first four chapters of the book explore the healing relationship and how a religious perspective can be a source of meaning for illness and death. Drawing on the work of Eric Cassell, a sick person is described as being not merely "a well person with a knapsack of illness strapped to his back", but a newly constituted human entity in need (page16).

There is an interesting section on the relationship between the healer and the sick person, drawing on insights from Isaiah's suffering servant chants. The authors see healing as coming about "through the suffering of others who themselves must suffer in order to heal" (page 24) and suggest that health professionals must suffer some ego-effacement and some loss of control in order to "suffer with". This leads on to a discussion of vulnerability as a principle in health care ethics.

It is not until chapter five that there is a discussion on religion and the 
principles of medical ethics, in particular a Christocentric ethic. This requires that any principle of ethical theory should conform to the spirit of love and justice exemplified by the life and teaching of Jesus Christ. A Christocentric ethic aims to transvalue the highest principles of philosophical ethics, justice and beneficence, into love, which thereby "carries them beyond the highest human aspirations" (page 69).

Noting the increased interest in medical ethics in the last 15 years, the authors are aware of the limited resources which are available. They suggest that ultimately what is at stake is the kind of society we want, or ought, to be (page 72).

The authors are at pains to impress upon the reader the need for a religious dimension to ethical decision-making and reiterate this in a variety of ways throughout the book, for example: "that a secular view might neglect important insights for medical ethics, public policy and the nature of medicine is a basic premise of this book" (page 75). However, although there is a lot of description, there is not much in terms of concrete suggestions about how incorporating a religious dimension into ethical decision-making might be achieved. For instance, they say "the calling to a task to build the earth and to live life in the spirit of altruism and charity does make a difference in the ways in which persons will analyze their own roles in the tasks of medicine. It also leads to a difference in analysis of ethical issues, as subsequent chapters will show" (page 76). The authors seem to be telling the reader what they will be saying, rather than just saying it and although there is nothing one could disagree with, the subsequent chapters seem rather vague and do not seem to come across with the goods in terms of the promised analysis.
It is not until the final two chapters that an attempt is made to "coalesce the ideas presented so far, with special attention to the specific obligations that the Christian health care ministry must adopt if it is to remain true to its calling" (page 126) and the book goes on to concentrate on the principles of love and justice and the challenge of economics and the marketplace to the "altruistic spirit that both faith and reason dictate in the care of the sick" (page 127). The authors try to argue on both philosophical and theological grounds that "the concepts of love and justice are inconsistent with the ethics of the marketplace, that all society is diminished when health care becomes a commodity and altruism is subverted by self-interest", and that "Christian understandings of love and justice go beyond the naturalistic interpretations and provide principles of discernment that shape the responsibilities of health care ministry for individual professionals, the institutional care of the sick, the formulation of health policy and the relationship of the institutional Church and the people of God to health and health care" (page 129). A tall order. Indeed, given the size of the book perhaps a narrower focus might have proven more successful!

It is not until page 136 that we come to a helpful analysis of the root principles of philosophical medical ethics the beneficence and justice so often mentioned - and some interesting questions are raised on the relationship between health care and social justice. However, the authors again detract from their useful comments in this section and turn instead to the theological perspectives on love and justice which form the final chapter of the book.

This final chapter, which "develops the last steps of our argument about how love and justice would shape our vision of a just and loving health caren ministry" (page 146) is divided int three sections; the Theological Pere? spective, Christocentric Health Care Ethics and The Call of the Whole Church to the Healing Ministry.

The authors conclude by saying tha "the Christian healing ministry rests? on the mystery of the patient who wa Christ, whose suffering and victor was a redemption for the whole human race" (page 160) and urge the adoption of the vision set out by Pope Paul VI of "a healing ministry whictlow fuses the idea of the profession indis? solubly with the idea of vocation (page 160). They end by once agaip undermining what they have beeff attempting to do in this book by saying this is "a vision which committedo Christians will grasp without the labo을 rious argumentation we have provided here".

NICHOLAS FENNEMORI
Senior Chaplain, Oxford Radcliffe Hospita
Oxfo
Books: information and
orders

If you wish to order or require further information regarding the tides re $\$$ viewed here, please write to or tel ephone the BMJ Bookshop, PO Bo 295, London WC1H 9JR. TeB 0171383 6244. Fax: 01713836662 Books are supplied post free in the UK and for BFPO addresses. Overseas:customers should add 15 per cent fợ postage and packing. Payment can b made by cheque in sterling drawn on UK bank or by credit card (Master. card, Visa, or American Express, stai ing card number, expiry date, and fue name (The price and availability are occasionally subject to revision by the publishers). 